Periodontal and chronic kidney disease

\title{
Periodontal and chronic kidney disease association: a systematic review and
} meta-analysis

Kostas Kapellas $^{1 *}$, Ankur Singh ${ }^{1,2}$, Maitê Bertotti $^{3}$, Gustavo Nascimento ${ }^{4}$, Lisa M. Jamieson $^{1}$ on behalf of the Perio-CKD collaboration

1. Australian Research Centre for Population Oral Health, The University of Adelaide, South Australia, Australia

2. Melbourne School of Population and Global Health, The University of Melbourne, Australia

3. School of Dentistry, Universidade Federal do Rio Grande do Sul, Brazil

4. Department of Dentistry and Oral Health, Aarhus Universitet Institut for Odontologi, Aarhus, Denmark

\section{Corresponding author}

Kostas Kapellas: Australian Research Centre for Population Oral Health;

Adelaide Dental School

Level 9, 57 North Terrace, Adelaide South Australia 5005;

Tel: +61883137339

Email: kostas.kapellas@adelaide.edu.au

Word Count: 2943/4000; Abstract: 199/250; References: 51; Figures: 2; Tables: 2

This is the author manuscript accepted for publication and has undergone full peer review but has not been through the copyediting, typesetting, pagination and proofreading process, which may lead to differences between this version and the Version of Record. Please cite this article as doi: 10.1111/nep.13225

This article is protected by copyright. All rights reserved. 


\title{
Periodontal and chronic kidney disease association: a systematic review and
} meta-analysis

\begin{abstract}
Aim: Chronic kidney disease (CKD) and kidney failure is increasing globally and evidence from observational studies suggest periodontal disease may contribute to kidney functional decline.

Methods: Electronic searches of the PubMed, EMBASE, Web of Science, Scopus and Cochrane Library databases were conducted for the purposes of conducting a systematic review. Hand searching of reference lists was also performed. Metaanalysis of observational studies involving periodontal disease and chronic kidney disease in adults was performed.
\end{abstract}

Results: A total of 17 studies were selected from an initial 4,055 abstracts. Pooled estimates indicated the odds of having $\mathrm{CKD}$ were $60 \%$ higher among patients with periodontitis: pooled OR $1.60\left(95 \%\right.$ CI $\left.1.44-1.79, \mathrm{I}^{2} 35.2 \%, P=0.11\right)$ compared to those without. Conversely, a similar magnitude but non-significant higher odds of having periodontal disease was found among people with CKD 1.69 (95\% CI: 0.84, $\left.3.40, \mathrm{I}^{2}=89.8 \%, P<0.00\right)$ versus non-CKD. Meta-regression revealed study quality based on the Newcastle-Ottawa Scale and statistical adjustment for potential

This article is protected by copyright. All rights reserved. 
confounders explained almost $35 \%$ of the heterogeneity in the studies investigating the association between $\mathrm{CKD}$ and periodontitis.

Conclusions: Moderate evidence for a positive association between periodontitis and CKD exists. Evidence for the opposite direction is extremely weak based on significant heterogeneity between studies.

Keywords: periodontal diseases; renal insufficiency, chronic; review, systematic; meta-analysis

\section{BACKGROUND}

Periodontitis is an inflammatory condition of the connective tissues around teeth. It is characterized by localized destruction of these tissues and, in severe cases, leads to tooth loss. This inflammation is caused by a unique set of bacteria which stimulate both innate and adaptive immune responses ${ }^{1}$. Chronic kidney disease (CKD) for the present review is defined by the glomerular filtration rate (GFR) below $60 \mathrm{~mL} / \mathrm{min} / 1.73 \mathrm{~m}^{2}$ for at least three months ${ }^{2}$. End-Stage Kidney Disease (ESKD) is diagnosed when GFR is $15 \mathrm{~mL} / \mathrm{min} / 1.73 \mathrm{~m}^{2}$ or below. Severe periodontitis was ranked as the $6^{\text {th }}$ most prevalent condition among 291 conditions $^{3}$ and CKD was ranked as the $13^{\text {th }}$ leading cause of death in the Global Burden of Disease study ${ }^{4}$.

Risk factors for CKD include increasing age ${ }^{2}$, hypertension ${ }^{2,5-7}$, sub-optimally managed diabetes ${ }^{2,5-7}$, tobacco smoking ${ }^{6}$, racial background ${ }^{8}$ and systemic inflammation ${ }^{9}$. Likewise, smoking ${ }^{10,11}$, increasing age ${ }^{12,13}$ and diabetes ${ }^{14}$ have been identified as risk factors for periodontal disease. 
Proposed mechanisms connecting periodontitis with CKD may involve systemic inflammation. During active phases of periodontitis, locally produced inflammatory cytokines such as interleukin- 6 and tumor necrosis factor- $\alpha$ act systemically to raise C-reactive protein levels ${ }^{15,16}$ which may lead to the progression of CKD. An alternative theory suggests that periodontal bacteria (or their lipopolysacharides) enter the systemic circulation and exert their effects beyond the periodontium $^{17,18}$. If a causal relationship between periodontitis and CKD were proven, periodontal treatment may reduce the risk of $\mathrm{CKD}^{19}$. Conversely, it is possible that CKD may mechanistically influence the onset and/or progression of periodontal disease, possibly mediated by diabetes and hypertension ${ }^{20}$.

The association between periodontal disease and CKD is presently unclear making it necessary to systematically assess the literature to verify if an association exists. Therefore, the purpose of this review is to evaluate existing evidence from published literature to determine, whether: 1) periodontitis is a risk factor for $\mathrm{CKD}$, and 2) CKD is a risk factor for periodontitis.

\section{METHODS}

The protocol for this systematic review was registered with the International Prospective Register for Systematic Reviews

(http://www.crd.york.ac.uk/PROSPERO/), registration number CRD42016033770. The MOOSE guidelines ${ }^{21}$ were used as the preparatory framework for this review. $\underline{\mathrm{PICO}}$ 
This review will attempt to answer two questions:

1) Are people with periodontal disease compared to those without periodontal disease more likely to have CKD?

Population: Adults with clinically-determined periodontal disease, Intervention: none, Comparator: Adults without clinically-determined periodontal disease, Outcome: Chronic kidney disease determined by GFR below $60 \mathrm{~mL} / \mathrm{min} / 1.73 \mathrm{~m}^{2}$.

2) Are people with CKD compared to those without CKD more likely to have periodontal disease?

Population: Chronic kidney disease determined by GFR below $60 \mathrm{~mL} / \mathrm{min} / 1.73 \mathrm{~m}^{2}$, Intervention: none, Comparator: Adults with GFR e $60 \mathrm{~mL} / \mathrm{min} / 1.73 \mathrm{~m}^{2}$, Outcome: adults with clinically-determined periodontal disease.

$\underline{\text { Study designs included in this review }}$

Cross-sectional, case-control and cohort studies were included if the association with periodontitis was examined in CKD patients, or if the presence of CKD was examined in periodontitis patients. Additionally, baseline data from any interventional studies that met the inclusion criteria were extracted and included in the meta-analysis.

Type of participants and inclusion criteria

Studies were included if they measured periodontal status via clinical oral assessments of periodontal pocket depth (PPD) and/or clinical attachment level (CAL) while studies solely reliant on using radiographic or visual criteria to determine periodontal status were excluded. For CKD, studies were included when GFR was calculated or assessed to be at Stage 1 or worse.

Excluded studies

This article is protected by copyright. All rights reserved. 
Case reports, literature reviews, commentaries and editorials were not included in this review. Additionally, studies in languages other than English were excluded.

\section{$\underline{\text { Search Strategy \& Sources }}$}

Electronic searches of PubMed, EMBASE, Web of Science, Scopus and Cochrane Library databases were conducted. Searches for eligible studies in this review were performed in duplicate by two authors both of whom are dental clinicians (KK and $\mathrm{MB}$ ) with the aid of a university research librarian according to search criteria presented in Supplement Table 2.

All databases were searched up to and including $31^{\text {st }}$ March 2017. Reference lists of previous reviews ${ }^{22}$ and of selected full-text articles were manually searched for additional articles. Both reviewers (KK and $\mathrm{MB}$ ) independently screened the titles and abstracts and if found to be relevant, the full text of each article was evaluated for final inclusion. Disagreement between reviewers was resolved via discussion.

Guidelines to engage a third reviewer in the event of unresolved disagreements were formulated but never used. Authors of selected articles for this review were contacted by email to glean additional information if required.

\section{Quality assessments}

Each study was evaluated according to the Newcastle Ottawa Scale ${ }^{23}$ for case-control and cohort studies and a modified version adapted for cross-sectional studies ${ }^{24}$ of the same scale was used (Supplement). The maximum score for cross-sectional studies was 10 . Articles that were assigned with 9-to-10 stars were deemed to be of 'High' quality, while scores 7-to-8 were ascribed as being of 'Moderate' quality and scores 6 
or lower were deemed to be of 'Low' quality. The maximum score for both cohort and case-control studies was nine. Articles that were assigned with values of 8-to-9 were classified as 'High' quality, while a score of 7 was assigned 'Moderate' quality and 'Low' were assigned for studies with 6 or less stars.

\section{$\underline{\text { Data Extraction }}$}

Data from each included study relating to: 1) author and year of publication, 2) country of study, 3) sample size and population of focus, 4) study design, 5) periodontitis case definition, 6) CKD definition, 7) statistical analysis approach and crude/adjusted results were recorded into data extraction forms.

Statistical-analysis was conducted to address the two research questions assessing bidirectional association between periodontal and kidney disease. Studies that met the inclusion criteria and reported periodontal status were included in the meta-analysis, irrespective of study design. Effect estimates reported in each study were pooled collectively using odds ratios (ORs). To allow the greatest number of studies to be included in the meta-analysis, effect estimates (e.g. risk ratio) were converted to ORs if they reported any effect estimate other than odds ratio. Where periodontitis was stratified by severity, data pertaining to the most severe definition were included in the meta-analyses. Choice between random- and fixed-effect models were decided based on estimated heterogeneity in each meta-analysis. Random-effect models were preferred due to known heterogeneities in study designs, periodontal disease case definitions or periodontal assessment methods prior to meta-analysis. Funnel plot and Egger's test were used to test for publication bias. Meta-regression 
and subgroup analyses were employed to investigate whether study characteristics influenced between-study variability. All analyses were performed using the software Stata 13.1 (StataCorp, College Station, TX, USA).

\section{RESULTS}

\section{$\underline{\text { Results of search }}$}

Figure 1 shows the flowchart for the search and study selection process. A total of 17 studies were selected and included of which nine studies reported periodontal disease as the exposure and CKD as the outcome. ${ }^{5,25-32}$ Alternately, eight reported the association of $\mathrm{CKD}$ as the exposure and periodontal disease as the outcome $\mathrm{e}^{33-40}$.

\section{Description of included studies}

For brevity, unless otherwise indicated, all presentations of ORs herein are adjusted results. Specific details of variables that were included in the adjustment process for each study are included in the legends of Tables $1-2$. Overall, eight of nine studies reporting associations between $\mathrm{PD}$ and $\mathrm{CKD}$ were judged to be of 'high' quality and one was deemed to be of 'moderate' quality using the NOS (Table $1 \&$ Supplement Tables 4-6). Conversely, only two studies reporting on associations between CKD and PD were deemed to be of 'high' quality, while four were 'moderate' and two studies were considered to be of 'low' quality according to the NOS criteria (Table 2 and Supplement Tables 4-6).

GFR was consistently used between studies to diagnose CKD or ESRD. In contrast, an array of measures and classification criteria were used to assess 
periodontal disease. These included the Community Periodontal Index (CPI $)^{29}$ or the CPI of Treatment Need (CPITN) ${ }^{26,39}$, Periodontal Inflamed Surface Area (PISA) ${ }^{30}$, Centres for Disease Control and American Academy of Periodontology (CDCAAP) ${ }^{28,36,38}$, American Academy of Periodontology $1999^{27}$, European Federation of Periodontology $y^{28,38}$ or no formal disease classification ${ }^{5,25,31-35,37,40}$.

$\underline{\text { Results of meta-analysis }}$

For the association between periodontal disease and the outcome of CKD, the combined sample size across the studies was 141,920 . Overall, pooled estimates from the nine included studies showed that individuals with periodontal disease had 1.60 (95\% CI 1.44, 1.79) times higher odds of having CKD (Figure 2A). Following sensitivity analysis, studies which presented crude results independently revealed that individuals with periodontal disease had $1.80(95 \%$ CI $1.15,2.82)$ times higher odds of having CKD (Supplementary Figure 1A) while the magnitude of the association between periodontitis and CKD was attenuated when the analysis was limited to adjusted results 1.60 (95\% CI 1.44, 1.79) (Supplementary Figure 1B).

The combined sample size of the association between CKD and the outcome of periodontal disease was 13,972 . Pooled estimates from the eight included studies revealed a similar magnitude, but non-significant higher odds of having periodontal disease among people with CKD 1.69 (95\% CI: 0.84, 3.40) (Figure 2B). We explored all methodological covariates as potential sources of heterogeneity in meta-regression analysis for the association between $\mathrm{CKD}$ and the outcome periodontal disease. Only statistical adjustment for confounding and study quality notably contributed to 
heterogeneity (Supplement Table 1). The estimated OR for 'high' quality 1.50 (95\% CI 1.10, 2.03) and 'moderate' quality studies OR 0.88 (95\% CI $0.22,3.48)$ served to attenuate the larger but-not-significant effect estimate produced by the two 'low' quality studies OR 6.74 (95\% CI 0.45, 101.17) (Figure 2B). Pooled estimated effect sizes of smaller magnitude were also in studies that only presented crude estimates. Collectively, these methodological aspects explained approximately $35 \%$ of the heterogeneity between studies (Supplement Table 1).

The funnel plots for the association between periodontal disease as the exposure and $\mathrm{CKD}$ as outcome showed homogeneity (Figure 2C). Conversely, the association between CKD and periodontal disease exhibited significant heterogeneity $\mathrm{I}^{2} 89.8 \%, P=<0.01$ (Figures $2 \mathrm{~B} \& 2 \mathrm{D}$ ). The Egger's test for publication bias for both directions of association were non-significant (Figures 2C and 2D). Due to the small number of studies included in each meta-analysis, it is unclear whether this was due to lack of power or a true indication of publication bias.

\section{DISCUSSION}

This review reports evidence of a bi-directional association between periodontal disease and CKD. The methodological quality of included studies was relatively higher for those examining periodontal disease as the exposure and CKD as outcome compared to the converse association. Periodontitis has been implicated to influence a myriad of conditions including diabetes, ${ }^{14}$ hypertension, ${ }^{41}$ vascular disease ${ }^{42,43}$ and even difficulties in conception. ${ }^{44}$ Periodontal disease is highly prevalent, affecting a 
quarter of the Australian adult population ${ }^{13}$ and up to half the U.S. adult population. ${ }^{12}$ Likewise, it is estimated that $15 \%$ of U.S. adults have $\mathrm{CKD}^{45}$ while in Australia, biomedical results from the most recent national health survey estimate that $10 \%$ of adults, equivalent to 1.7 million people have $\mathrm{CKD} .{ }^{2}$ Given that both conditions share common risk factors, positive associations are unsurprising.

Unlike criteria used to distinguish the presence of $\mathrm{CKD},{ }^{2}$ defining and classifying periodontal disease has been contentious ${ }^{46}$ leading to differences in its diagnosis across the world. Consequently, an array of criteria has been developed describing historical disease experience (CAL), current disease processes (PPD and BOP), which sites in the mouth should be assessed, and how. In order to incorporate as many studies as possible in the meta-analyses, we elected to include studies if the periodontal status was clinically measured rather than limiting to a particular periodontitis case definition. In doing so, this was at the expense of homogeneity in the meta-analyses. While all studies included in the periodontal disease and CKD association meta-analysis had specified case definitions for periodontitis, four of the eight studies included in the CKD and periodontal disease association meta-analysis did not use a formal case definition.

The association between $\mathrm{CKD}$ and periodontal disease may have been influenced by the level of impaired renal function. In this meta-analysis, a pragmatic approach to combine all stages of CKD into a single 'diseased' group may have inflated the effect estimate given than half of the studies included in the meta-analysis involved ESKD patients with GFR levels at or below $15 \mathrm{~mL} / \mathrm{min} / 1.73 \mathrm{~m}^{2}$. Patients 
with ESKD have repeated bouts of uremic syndrome when not dialyzed which, in turn, impairs the normal immune function of monocytes and polymorphonuclear lymphocytes. ${ }^{47}$ Consequently, overgrowth of periodontopathic bacteria in the presence of ESKD is possible. Studies by Takeuchi et al. ${ }^{48}$ and Bastos and colleagues ${ }^{33}$ both reported that the periodontopathogens Tannarella forsythia and Treponema denticola, were more often detected within the periodontal tissues of haemodialysis patients compared to their respective non-CKD control groups. Further, the concentration of T. forsythia, Porphyromonas gingivalis, Prevotella intermedia and Prevotella nigrescens were significantly higher among haemodialysis patients compared to non-CKD controls in the study by Castillo and colleagues. ${ }^{49}$ Of interest, stratification by extent of loss of periodontal attachment (LPA) e $3 \mathrm{~mm}$ among the haemodialysis group revealed that there were no significant differences in the concentrations of T. forsythia, P. gingivalis or P. intermedia when comparing individuals with low levels of LPA against those expressing high levels of disease. ${ }^{49}$ This suggests that differences may not be due to periodontal disease per se but rather that renal disease influences bacterial composition.

A strength of the present review are the sample sizes of the two meta-analyses. The large sample sizes are mostly attributed to the investigations which used representative survey data of the general populations in the USA ${ }^{5,27,28,32,36}$, South Korea $^{29}$ and Taiwan. ${ }^{26}$ Secondly, the systematic and methodical approach invested in formulating the search strategies for each of the four databases ensured that all potential studies eligible for inclusion were incorporated in this review. It was not 
pragmatic to search for articles that were published in languages other than English. For this reason, the possibility that potential publications were missed during the search process cannot be discounted. However, the 17 papers included in this review arose from nine different countries, seven of which do not have English as their official language. Therefore, the potential impact of excluding non-English publications may have been negligible. The internal validity and generalizability of the meta-analysis summarizing the association between periodontal disease and CKD is likely to be high on account that it was largely composed of adjusted estimates from each included study. Thus, it is expected that the influence of residual confounding would be minimal. Alternatively, adjusted estimates from the two studies included in the $\mathrm{CKD}$ and periodontal disease association are conceivably too few to make that meta-analysis externally valid.

Cohort studies from Japan, ${ }^{30}$ Taiwan, ${ }^{26}$ and the U.S. ${ }^{28,50,51}$ have shown that periodontal disease is associated with the incidence of CKD, or decline in renal function. This builds on the present finding which estimates that periodontal disease imparts a $60 \%$ higher odds of having CKD. Diagnosis, treatment and management of patients with periodontitis should form part of routine dental care for all people. The evidence presented herein indicates that patients with suspected or confirmed CKD may benefit from undergoing a periodontal assessment and receiving treatment if a positive diagnosis is made. Despite no studies to date having investigated the incidence or progression of periodontal disease among CKD patients, and given the shared risk factors for both conditions, it would be advisable that periodontal care 
form part of the standard CKD management regimen. Future research should aim to determine whether providing periodontal treatment will result in improved GFR, particularly among those with early evidence of impaired renal function. Current efforts in this venture have, for various reasons, been equivocal. ${ }^{25,52-56}$

\section{CONCLUSION:}

We find moderate evidence in association to the presence of PD in CKD patients while the evidence for the opposite direction is extremely weak. Given that the studies included in this review were all observational, the level of evidence can be considered 'low' at best. Inconsistencies in the criteria used to define periodontitis and in the selection of study participants hamper comparisons. Given that chronic inflammation among patients with CKD and ESKD exacerbates health concerns in this population, pragmatic measures to reduce systemic inflammation, such as periodontal treatment, may have long-term benefits. Additional studies among patients with periodontitis and CKD which measure GFR prospectively are required to further understand potential causative mechanisms.

\section{ACKNOWLEDGMENTS}

The authors gratefully acknowledge the assistance of Michael Draper, University of Adelaide research librarian for his guidance during development of the database search strategies. The authors also wish to acknowledge the feedback and guidance provided by the Perio-CKD research collaboration which consists of the following: 
Nephrologists (Jaqui Hughes, Cherian Sajiv, David Fernandes, Basant Pawar, David Harris, Wendy Hoy and Alan Cass), Endocrinologist (Louise Maple-Brown), General Practice (Alex Brown), cardiovascular physiology (Micheal Skilton), clinical trials (Lisa Askie), Periodontist (P Mark Bartold), Oral Epidemiologist (Peter Arrow). KK developed the search criteria, conducted the database and hand-searches, extracted data and prepared the manuscript as the corresponding author. MB conducted the database searches and was involved in screening articles for inclusion in addition to assisting in manuscript preparation. AS and GN conducted the metaanalysis and wrote the statistical methods section of this paper. Each co-author contributed important intellectual content during manuscript drafting or revision. KK accepts accountability for the overall work by ensuring that questions pertaining to the accuracy or integrity of any portion of the work are appropriately investigated and resolved. KK takes responsibility that this study has been reported honestly, accurately, and transparently; that no important aspects of the study have been omitted; and that any discrepancies from the study have been explained.

\section{SUPPORT AND FINANCIAL DISCLOSURE DECLARATION}

KK is supported by NHMRC Early Career Fellowship \#1113098 and reports no conflicts of interest. MB is supported by Universidade Federal do Rio Grande do Sul and has no commercial or associative interests that represents a conflict. 


\section{REFERENCES}

1 Meyle J, Chapple I. Molecular aspects of the pathogenesis of periodontitis. Periodontology 2000. 2015; 69: 7-17.

2 Australian Bureau of Statistics. National Health Survey: Biomedical Results for Chronic Diseases, 2012-2013 Australia. ABS Cat no4364055005. Canberra: Australian Bureau of Statistics 2013.

3 Kassebaum NJ, Bernabé E, Dahiya M, Bhandari B, Murray CJL, Marcenes W. Global Burden of Severe Periodontitis in 1990-2010: A Systematic Review and Metaregression. Journal of Dental Research. 2014; 93: 1045-53.

4 Vos T, Flaxman AD, Naghavi M, Lozano R, Michaud C, Ezzati M, et al. Years lived with disability (YLDs) for 1160 sequelae of 289 diseases and injuries 1990-2010: a systematic analysis for the Global Burden of Disease Study 2010. The Lancet. 2012; 380: 2163-96.

5 Fisher MA, Taylor GW, Shelton BJ, Jamerson KA, Rahman M, Ojo AO, et al. Periodontal Disease and Other Nontraditional Risk Factors for CKD. American Journal of Kidney Diseases. 2008; 51: 45-52.

6 Haroun MK, Jaar BG, Hoffman SC, Comstock GW, Klag MJ, Coresh J. Risk Factors for Chronic Kidney Disease: A Prospective Study of 23,534 Men and Women in Washington County, Maryland. Journal of the Americal Society of Nephrology. 2003; 14: 2934-41.

$7 \quad$ Vupputuri S, Sandler DP. Lifestyle Risk Factors and Chronic Kidney Disease. Annals of Epidemiology. 2003; 17: 712-20.

8 Australian Bureau of Statistics. Australian Aboriginal and Torres Strait Islander Health Survey: Biomedical Results, 2012-13. ABS cat no 47270550032014. 9 Tonelli M, Sacks F, Pfeffer M, Jhangri GS, Curhan G. Biomarkers of inflammation and progression of chronic kidney disease. Kidney International. 2005; 68: $237-45$.

10 Do L, Slade G, Roberts-Thomson K, Sanders A. Smoking-attributable periodontal disease in the Australian adult population. Journal of Clinical Periodontology. 2008; 35: 398-404.

11 Johannsen A, Susin C, Gustafsson A. Smoking and inflammation: evidence for a synergistic role in chronic disease. Periodontology 2000. 2014; 64: 111-26. 12 Eke PI, Dye BA, Wei L, Thornton-Evans GO, Genco RJ. Prevalence of Periodontitis in Adults in the United States: 2009 and 2010. Journal of Dental Research. 2012; 91: 914-20.

13 Roberts-Thomson K, Do L. Oral Health Status In: Slade G, Spencer A, Roberts-Thomson K (eds.). Australia's dental generations: the National Survey of Adult Oral Health 2004-06. Vol. Dental Statistics and Research Series No. 34. Canberra: Australian Institute of Health and Welfare 2007; 119.

14 Preshaw P, Alba A, Herrera D, Jepsen S, Konstantinidis A, Makrilakis K, et al. Periodontitis and diabetes: a two-way relationship. Diabetologia. 2012; 55: 21-31.

15 Moutsopoulos N, Madianos P. Low-Grade Inflammation in Chronic Infectious Diseases. Annals of the New York Academy of Sciences. 2006; 1088: 251-64. 
16 Dye B, Choudhary K, Shea S, Papapanou P. Serum antibodies to periodontal pathogens and markers of systemic inflammation. Journal of Clinical Periodontology. 2005; 32: 1189-99.

17 Hayashi C, Gudino CV, Gibson Iii FC, Genco CA. REVIEW: Pathogeninduced inflammation at sites distant from oral infection: bacterial persistence and induction of cell-specific innate immune inflammatory pathways. Molecular Oral Microbiology. 2010; 25: 305-16.

18 Pussinen PJ, Tuomisto K, Jousilahti P, Havulinna AS, Sundvall J, Salomaa V. Endotoxemia, Immune Response to Periodontal Pathogens, and Systemic Inflammation Associate With Incident Cardiovascular Disease Events. Arterioscler Thromb Vasc Biol. 2007; 27: 1433-39.

19 Craig RG, Kotanko P, Kamer AR, Levin NW. Periodontal diseases - a modifiable source of systemic inflammation for the end-stage renal disease patient on haemodialysis therapy? Nephrology Dialysis Transplantation. 2007; 22: 312-15. 20 Fisher MA, Taylor GW, West BT, McCarthy ET. Bidirectional relationship between chronic kidney and periodontal disease: a study using structural equation modeling. Kidney Int. 2011; 79: 347-55.

21 Stroup D, Berlin J, Morton S, Olkin I, Williamson G, Rennie D, et al. Metaanalysis of Observational Studies in Epidemiology: A Proposal for Reporting. JAMA. 2000; 283: 2008-12.

22 Chambrone L, Foz AM, Guglielmetti MR, Pannuti CM, Artese HPC, Feres M, et al. Periodontitis and chronic kidney disease: a systematic review of the association of diseases and the effect of periodontal treatment on estimated glomerular filtration rate. Journal of Clinical Periodontology. 2013; 40: 443-56.

23 Wells G, Shea B, O'Connell D, Peterson J, Welch V, Losos M, et al. The Newcastle-Ottawa Scale (NOS) for assessing the quality of nonrandomised studies in meta-analyses. 2014.

24 Herzog R, Álvarez-Pasquin MJ, Díaz C, Del Barrio JL, Estrada JM, Gil Á. Are healthcare workers' intentions to vaccinate related to their knowledge, beliefs and attitudes? a systematic review. BMC Public Health. 2013; 13: 154.

25 Artese HP, Sousa CO, Luiz RR, Sansone C, Torres MC. Effect of non-surgical periodontal treatment on chronic kidney disease patients. Brazilian Oral Research. 2010; 24: 449-54.

26 Chen Y-T, Shih C-J, Ou S-M, Hung S-C, Lin C-H, Tarng D-C. Periodontal Disease and Risks of Kidney Function Decline and Mortality in Older People: A Community-Based Cohort Study. American Journal of Kidney Diseases. 2015; 66: 223-30.

27 Grubbs V, Plantinga LC, Crews DC, Bibbins-Domingo K, Saran R, Heung M, et al. Vulnerable Populations and the Association between Periodontal and Chronic Kidney Disease. Clinical Journal of the American Society of Nephrology. 2011; 6: 711-17.

28 Grubbs V, Vittinghoff E, Taylor G, Kritz-Silverstein D, Powe N, BibbinsDomingo $\mathrm{K}$, et al. The association of periodontal disease with kidney function 
decline: a longitudinal retrospective analysis of the MrOS dental study. Nephrology Dialysis Transplantation. 2016; 31: 466-72.

29 Han SS, Shin N, Lee SM, Lee H, Kim DK, Kim YS. Correlation between periodontitis and chronic kidney disease in Korean adults. Kidney Research and Clinical Practice. 2013; 32: 164-70.

30 Iwasaki M, Taylor GW, Nesse W, Vissink A, Yoshihara A, Miyazaki H. Periodontal Disease and Decreased Kidney Function in Japanese Elderly. American Journal of Kidney Diseases. 2012; 59: 202-09.

31 Kshirsagar AV, Craig RG, Beck JD, Moss K, Offenbacher S, Kotanko P, et al. Severe Periodontitis Is Associated with Low Serum Albumin among Patients on Maintenance Hemodialysis Therapy. Clinical Journal of the American Society of Nephrology. 2007; 2: 239-44.

32 Kshirsagar AV, Moss KL, Elter JR, Beck JD, Offenbacher S, Falk RJ. Periodontal disease is associated with renal insufficiency in the Atherosclerosis Risk In Communities (ARIC) study. American Journal of Kidney Diseases. 2005; 45: 65057.

33 Bastos JA, Diniz CG, Bastos MG, Vilela EM, Silva VL, Chaoubah A, et al. Identification of periodontal pathogens and severity of periodontitis in patients with and without chronic kidney disease. Archives of Oral Biology. 2011; 56: 804-11. 34 Garcez J, Limeres Posse J, Carmona IT, Feijoo JF, Diz Dios P. Oral health status of patients with a mild decrease in glomerular filtration rate. Oral Surgery, Oral Medicine, Oral Pathology, Oral Radiology, and Endodontology. 2009; 107: 224-28. 35 Gavalda C, Bagan J, Scully C, Silvestre F, Milian M, Jimenez Y. Renal hemodialysis patients: oral, salivary, dental and periodontal findings in 105 adult cases. Oral Dis. 1999; 5: 299-302.

36 Ioannidou E, Swede H. Disparities in Periodontitis Prevalence among Chronic Kidney Disease Patients. Journal of Dental Research. 2011; 90: 730-34.

37 Marakoglu I, Gursoy UK, Demirer S, Sezer H. Periodontal Status of Chronic Renal Failure Patients Receiving Hemodialysis. Yonsei Med J. 2003; 44: 648-52. 38 Sharma P, Dietrich T, Sidhu A, Vithlani V, Rahman M, Stringer S, et al. The periodontal health component of the Renal Impairment In Secondary Care (RIISC) cohort study: a description of the rationale, methodology and initial baseline results. Journal of Clinical Periodontology. 2014; 41: 653-61.

39 Tiwari V, Saxena V, Bhambhal A, Tiwari U, Singh A, Goud S. The oral health status of patients with renal disease in central India: a preliminary study. Journal of Renal Care. 2013; 39: 208-13.

40 Torres SA, Rosa OPdS, Hayacibara MF, Guimarães MdCM, Hayacibara RM, Bretz WA. Periodontal parameters and BANA test in patients with chronic renal failure undergoing hemodialysis. Journal of Applied Oral Science. 2010; 18: 297-302. 41 Ahn Y-B, Shin M-S, Byun J-S, Kim H-D. The association of hypertension with periodontitis is highlighted in female adults: results from the Fourth Korea National Health and Nutrition Examination Survey. Journal of Clinical Periodontology. 2015; 42: 998-1005. 
42 Ahn Y-B, Shin M-S, Han D-H, Sukhbaatar M, Kim M-S, Shin H-S, et al. Periodontitis is associated with the risk of subclinical atherosclerosis and peripheral arterial disease in Korean adults. Atherosclerosis. 2016; 251: 311-18.

43 Kapellas K, Jamieson L, Do L, Bartold P, Wang H, Maple-Brown L, et al. Associations between periodontal disease and cardiovascular surrogate measures among Indigenous Australians. International Journal of Cardiology. 2014; 173: 190 96.

44 Hart R, Doherty DA, Pennell CE, Newnham IA, Newnham JP. Periodontal disease: A potential modifiable risk factor limiting conception. Hum Reprod. 2012; 27: $1332-42$.

45 Centers for Disease Control and Prevention. Chronic Kidney Disease Surveillance System - United States. Atlanta, Georgia: Centers for Disease Control and Prevention 2016.

46 Savage A, Eaton KA, Moles DR, Needleman I. A systematic review of definitions of periodontitis and methods that have been used to identify this disease. Journal of Clinical Periodontology. 2009; 36: 458-67.

47 Cohen G, Haag-Weber M, Horl WH. Immune dysfunction in uremia. Kidney international Supplement. 1997; 62: S79-82.

48 Takeuchi Y, Ishikawa H, Inada M, Shinozuka O, Umeda M, Yamazaki T. Study of the oral microbial flora in patients with renal disease. Nephrology. 2007; 12: 182-90.

49 Castillo A, Mesa F, Liébana J, García-Martinez O, Ruiz S, García-Valdecasas $\mathrm{J}$, et al. Periodontal and oral microbiological status of an adult population undergoing haemodialysis: a cross-sectional study. Oral Diseases. 2007; 13: 198-205.

50 Grubbs V, Vittinghoff E, Beck JD, Kshirsagar AV, Wang W, Griswold ME, et al. Association Between Periodontal Disease and Kidney Function Decline in African Americans: The Jackson Heart Study. Journal of Periodontology. 2015; 86: 1126-32. 51 Shultis WA, Weil EJ, Looker HC, Curtis JM, Shlossman M, Genco RJ, et al. Effect of Periodontitis on Overt Nephropathy and End-Stage Renal Disease in Type 2 Diabetes. Diabetes Care. 2007; 30: 306-11. 


\section{FIGURE LEGEND}

FIGURE 1: Flow diagram of the search process

FIGURE 2A: Forrest plot for the association between periodontal disease and the outcome of chronic kidney disease, stratified according to appraisal quality scores

FIGURE 2B: Forrest plot showing the association between chronic kidney disease and the outcome of periodontal disease, stratified according to appraisal quality scores

FIGURE 2C: Funnel plots demonstrating the degree of bias and heterogeneity within the analysed studies for the association between periodontal disease and the outcome of chronic kidney disease

FIGURE 2D: Funnel plots demonstrating the degree of bias and heterogeneity within the analysed studies for the association between chronic kidney disease and the outcome of periodontal disease 
Table 1: Periodontal disease associated with CKD

\begin{tabular}{|c|c|c|c|c|c|c|}
\hline Author/year & Setting & Sample Size & Study Design & CKD Definition & PD Definition & Analytical Approach \\
\hline Artese et al. $2010^{25}$ & Brazil & $\begin{array}{l}40 \text { subjects in total } \\
\text { CKD (pre-dialysis) } n=21 \\
\text { Non-CKD control } n=19\end{array}$ & $\begin{array}{l}\text { Quasi-experimental } \\
\text { study }\end{array}$ & $\begin{array}{l}\text { CKD: GFR between } 89 \text { and } \\
15 \mathrm{~mL} / \mathrm{min} / 1.73 \mathrm{~m}^{2}\end{array}$ & $\begin{array}{l}\text { PD: e } 4 \text { sites in } 3 \text { different } \\
\text { teeth with CAL e } 4 \mathrm{~mm} \& \\
\text { BOP. }\end{array}$ & $\begin{array}{l}\text { Chi sq and Wilcoxon signed- } \\
\text { rank test }\end{array}$ \\
\hline Chen et al $2015^{26}$ & Taiwan & $\begin{array}{l}\text { Total 100,263 Taiwan } \\
\text { residents } \\
\text { PD: } n=13,749 \\
\text { Non-PD: } n=86,514\end{array}$ & Prospective cohort & e $30 \%$ decline in eGFR. & CPITN & $\begin{array}{l}\text { Multivariable logistic } \\
\text { regression modelling }\end{array}$ \\
\hline Fisher et al $2008^{5}$ & USA & $\begin{array}{l}12,947 \text { adults (NHANES } \\
\text { III) } \\
\text { PD } n=1,271 \\
\text { Non-PD } n=10,066 \\
\text { Edentulous } n=1,610\end{array}$ & Cross-sectional & $\begin{array}{l}\text { GFR between } \\
60 \mathrm{~mL} / \mathrm{min} / 1.73 \mathrm{~m}^{2} \\
\& \text { e } 15 \mathrm{~mL} / \mathrm{min} / 1.73 \mathrm{~m}^{2}\end{array}$ & $\begin{array}{l}\text { e } 1 \text { site with e } 4 \mathrm{~mm} \text { LOA + } \\
\text { BOP }\end{array}$ & $\begin{array}{l}\text { Multivariable logistic } \\
\text { regression modelling }\end{array}$ \\
\hline Grubbs et al $2011^{27}$ & USA & $\begin{array}{l}\text { 6,199 adults aged } \mathrm{e} 21 \text { and } \\
\mathrm{d} 75 \text { years } \\
\text { NHANES 2001-2004 } \\
\text { Mod/Severe PD } \mathrm{n}=\sim 329\end{array}$ & Cross-sectional & $\begin{array}{l}\text { GFR between } \\
60 \mathrm{~mL} / \mathrm{min} / 1.73 \mathrm{~m}^{2} \\
\& \text { e } 15 \mathrm{~mL} / \mathrm{min} / 1.73 \mathrm{~m}^{2}\end{array}$ & $\begin{array}{l}\text { e } 2 \text { IP sites with e } 3 \mathrm{~mm} \text { CAL } \\
\& \text { e } 2 \text { IP sites with e } 4 \mathrm{~mm} \\
\text { PPD or e } 1 \text { site with PPD e } 5 \\
\text { mm. }\end{array}$ & $\begin{array}{l}\text { Chi sq and Multivariate } \\
\text { correlations }\end{array}$ \\
\hline Grubbs et al $2016^{28}$ & USA & 761 men aged $\geq 65$ years & $\begin{array}{l}\text { Retrospective } \\
\text { cohort }\end{array}$ & $\begin{array}{l}\text { Incident } \\
\text { eGFR }<60 \mathrm{~mL} / \mathrm{min} / 1.73 \mathrm{~m}^{2} \\
\& \\
\text { e } 5 \% \text { decline in eGFR }\end{array}$ & $\begin{array}{l}\text { European Workshop \& } \\
\text { CDC/AAP "severe" } \\
\text { classifications }\end{array}$ & $\begin{array}{l}\text { Multivariable Poisson } \\
\text { regression }\end{array}$ \\
\hline Han et al $2013^{29}$ & South Korea & $\begin{array}{l}15,729 \text { adults participating } \\
\text { in the Korean NHANES }\end{array}$ & Cross-sectional & GFR $<60 \mathrm{~mL} / \mathrm{min} / 1.73 \mathrm{~m} 2$. & $\begin{array}{l}\text { CPI score e } 3 \text { in any index } \\
\text { teeth }\end{array}$ & Multivariate logistic model \\
\hline
\end{tabular}




\begin{tabular}{|c|c|c|c|c|c|c|}
\hline Iwasaki et al $2012^{30}$ & Japan & 317 participants $\geq 75$ years & $\begin{array}{l}\text { Retrospective } \\
\text { cohort }\end{array}$ & GFR & $\begin{array}{l}\text { PISA* } \\
4^{\text {th }} \text { PISA quartile vs PISA } \\
\text { quartiles } 1-3\end{array}$ & Multivariate logistic model \\
\hline $\begin{array}{l}\text { Kshirsagar et al } \\
2005^{32}\end{array}$ & USA & $\begin{array}{l}5,537 \text { individuals from } \\
\text { ARIC study (US) } \\
\text { Healthy/Gingivitis n=2,314 } \\
\text { Initial PD n=2,276 } \\
\text { Severe PD n=947 }\end{array}$ & Cross-sectional & GFR $<60 \mathrm{~mL} / \mathrm{min} / 1.73 \mathrm{~m}^{2}$ & $\begin{array}{l}\text { Healthy/gingivitis } \\
\text { Initial: e } 2 \text { IP sites e } 4 \mathrm{~mm} \text { of } \\
\text { CAL (not on the same tooth) } \\
\text { Severe: e } 2 \text { IP (not on the same } \\
\text { tooth) with a CAL e } 6 \mathrm{~mm} \\
\text { and e } 1 \text { PPD of e } 5 \mathrm{~mm} \text {. }\end{array}$ & Multivariate logistic model \\
\hline $\begin{array}{l}\text { Kshirsagar et al } \\
2007^{31}\end{array}$ & USA & $\begin{array}{l}154 \text { hemodialysis patients. } \\
\text { Severe PD n=35 } \\
\text { Non-PD/Mild/Moderate } \\
\text { PD n=119 }\end{array}$ & Cross-sectional & $\begin{array}{l}\text { ESKD GFR } \\
\mathrm{d} 15 \mathrm{~mL} / \mathrm{min} / 1.73 \mathrm{~m}^{2} \\
\text { Low serum albumin, defined } \\
\text { as }<3.5 \mathrm{mg} / \mathrm{dl} \text {, and high CRP, } \\
\text { defined as }>3.0 \mathrm{mg} / \mathrm{dl}\end{array}$ & $\begin{array}{l}\text { Severe periodontitis: e } 60 \% \text { of } \\
\text { sites with CAL e } 4 \mathrm{~mm}\end{array}$ & Multivariate logistic model \\
\hline
\end{tabular}

\section{Table 1: Periodontal disease associated with CKD (cont.)}

\begin{tabular}{|l|l|l|l|l|}
\hline Author/year & $\begin{array}{l}\text { Effect size and Crude } \\
\text { Association with 95\%CI }\end{array}$ & Adjusted effect & $\begin{array}{l}\text { Variables used in adjusted } \\
\text { models }\end{array}$ & $\begin{array}{l}\text { NOS quality } \\
\text { assessment }\end{array}$ \\
\hline Artese et al. 2010 & Not reported & Not reported & N/A & High \\
\hline Chen et al $2015^{26}$ & PD vs non-PD ref & PD vs non-PD ref & Age, sex, BMI, smoking, alcohol & High \\
& eGFR decline & eGFR decline & use, SBP \& DBP, eGFR, & \\
& 1yr: HR 0.99 $(0.82-1.19)$ & 1yr: Adj HR 1.03 $(0.85-1.25)$ & hypertension, diabetes mellitus, \\
& 2yr: HR 1.56 (1.36-1.79) & 2yr: Adj HR 1.62 (1.41-1.87) & coronary artery disease, \\
& 3yr: HR 1.54 (1.33-1.79) & 3yr: Adj HR 1.59 (1.37-1.86) & cerebrovascular disease, fasting & \\
\hline
\end{tabular}




\begin{tabular}{|c|c|c|c|c|}
\hline & & & $\begin{array}{l}\text { glucose level, white blood cell } \\
\text { count, urinary protein level, serum } \\
\text { total and HDL, triglyceride, } \\
\text { haemoglobin, uric acid, urea } \\
\text { nitrogen, albumin levels. }\end{array}$ & \\
\hline Fisher et al $2008^{5}$ & $\frac{\text { Non-PD (ref) }}{\text { OR } 1.26(0.78 \text { to } 2.03)}$ & $\frac{\text { Non-PD (ref) }}{\text { Adj OR } 1.20(0.76-1.90)}$ & $\begin{array}{l}\text { Age, gender, tobacco, race, } \\
\text { hypertension, annual physician } \\
\text { visit, LDL, macroalbuminuria, } \\
\text { income, high total cholesterol, } \\
\text { hospitalisation within past year. }\end{array}$ & High \\
\hline Grubbs et al $2011^{27}$ & $\begin{array}{l}\text { Non-PD/mild PD (ref) } \\
\text { OR } 2.50(1.96 \text { to } 3.19)\end{array}$ & $\frac{\text { Non-PD/mild PD (ref) }}{\text { Adj OR } 1.51(1.13-2.02)}$ & $\begin{array}{l}\text { Age, gender, tobacco, diabetes, } \\
\text { hypertension, race, educational } \\
\text { attainment, poverty status \& dental } \\
\text { care use. }\end{array}$ & High \\
\hline Grubbs et al $2016^{28}$ & $\begin{array}{l}\text { European Workshop } \\
\text { IRR } 2.42(1.45-4.02)\end{array}$ & $\begin{array}{l}\text { European Workshop } \\
\text { Adj IRR } 2.04(1.21-3.44)\end{array}$ & $\begin{array}{l}\text { Age, diabetes, hypertension, } \\
\text { tobacco use, race and education. }\end{array}$ & High \\
\hline Han et al $2013^{29}$ & $\begin{array}{l}\text { Non-PD (ref) } \\
\text { OR } 4.07 \text { (3.11 to } 5.33)\end{array}$ & $\begin{array}{l}\text { Non-PD (ref) } \\
\text { OR } 1.39(1.03-1.89)\end{array}$ & $\begin{array}{l}\text { Age, sex, region, education, } \\
\text { obesity, smoking, exercise, } \\
\text { hypertension, diabetes, } \\
\text { hypercholesterolemia, CVD }\end{array}$ & High \\
\hline Iwasaki et al $2012^{30}$ & $\begin{array}{l}\text { Highest PISA vs PISA quartiles } \\
1-3 \\
\text { Decreased eGFR } \\
\text { OR } 2.58(1.34 \text { to } 4.98)\end{array}$ & $\begin{array}{l}\text { Highest PISA vs PISA quartiles } \\
1-3 \\
\text { Decreased eGFR } \\
\text { Adj OR } 2.24(1.05-4.79)\end{array}$ & $\begin{array}{l}\text { Age, smoking, dental visiting } \\
\text { pattern, hyperglycaemia, } \\
\text { hypoalbuminemia }\end{array}$ & Moderate \\
\hline Kshirsagar et al $2005^{32}$ & $\begin{array}{l}\text { Healthy/Gingivitis (ref) } \\
\text { Initial PD: OR } 2.10 \text { (1.33-3.31) }\end{array}$ & $\begin{array}{l}\text { Healthy/Gingivitis (ref) } \\
\text { Initial PD: Adj OR } 2.00(1.23-\end{array}$ & $\begin{array}{l}\text { Age, ARIC field centre, race, sex, } \\
\text { diabetes, hypertension, BMI, } \\
\text { education level, 5-level smoking }\end{array}$ & High \\
\hline
\end{tabular}




\begin{tabular}{|c|c|c|c|c|}
\hline & Severe PD: OR 2.21 (1.28-3.82) & $\begin{array}{l}3.24) \\
\text { Severe PD: Adj OR } 2.14 \text { (1.19- } \\
\text { 3.85) }\end{array}$ & status and serum CRP. & \\
\hline Kshirsagar et al $2007^{31}$ & $\begin{array}{l}\text { Non-periodontitis/mild/moderate } \\
\text { ref } \\
\text { Severe PD: OR } 3.23 \text { (1.16 to } \\
8.96 \text { ) }\end{array}$ & $\begin{array}{l}\text { Non-periodontitis/mild/moderate } \\
\underline{\text { ref }} \\
\text { Severe PD: Adj OR } 8.20 \text { (1.61 - } \\
41.82)\end{array}$ & $\begin{array}{l}\text { Age, gender, race, diabetes, } \\
\text { hypertension, BMI, smoking, } \\
\text { study site, nPCR, serum calcium, } \\
\text { serum phosphorus and total } \\
\text { cholesterol. }\end{array}$ & High \\
\hline
\end{tabular}

Abbreviations: GFR: glomerular filtration rate; CKD: chronic kidney disease; ESKD: end-stage kidney disease; CRP: C-reactive protein; PPD: probing pocket depth; CAL: clinical attachment level; IP: interproximal; NHANES: National Health and Nutritional Examination Survey; ARIC: Atherosclerosis Risk in Communities Study; CDC/AAP: Centres for Disease Control and Prevention and American Academy of Periodontology; EFP: European Federation of Periodontology; PD: periodontal disease; Chi Sq: chi square. 
Table 2: Observational Studies: CKD associated with Periodontitis

\begin{tabular}{|c|c|c|c|c|c|c|}
\hline Authors & Setting & Sample Size & Study Design & CKD Definition & PD Definition & Analytical Approach \\
\hline $\begin{array}{l}\text { Bastos et al } \\
2011^{33}\end{array}$ & Brazil & $\begin{array}{l}66 \text { chronic periodontal patients } \\
\text { in total } \\
\text { Non-CKD: } \mathrm{n}=19 ; \\
\text { Pre-dialysis group: } \mathrm{n}=25 \text {; } \\
\text { RRT group: } \mathrm{n}=22\end{array}$ & Case-control & $\begin{array}{l}\text { Presence of albuminuria, } \\
\text { glomerular hematuria, } \\
\text { structural abnormalities } \\
\text { or GFR } \\
<60 \mathrm{~mL} / \mathrm{min} / 1.73 \mathrm{~m}^{2}\end{array}$ & $\begin{array}{l}\text { e } 2 \text { teeth with e } 6 \mathrm{~mm} \mathrm{CAL} \\
\& \text { e } 1 \text { site with e } 5 \mathrm{~mm} \text { PPD. }\end{array}$ & t-test \\
\hline $\begin{array}{l}\text { Garcez et al } \\
2009^{34}\end{array}$ & Spain & $\begin{array}{l}160 \text { total } \\
\text { Reduced GFR : } n=80 \\
\text { Healthy GFR: } n=80\end{array}$ & Case-control & $\begin{array}{l}\text { GFR e } 60 \text { \& } \\
\mathrm{d} 89 \mathrm{~mL} / \mathrm{min} / 1.73 \mathrm{~m}^{2}\end{array}$ & $\begin{array}{l}\text { No case definition. } \\
\text { Ramfjord teeth examined }\end{array}$ & t-test \\
\hline $\begin{array}{l}\text { Gavalda et al } \\
1999^{35}\end{array}$ & Spain & $\begin{array}{l}\text { Hemodialysis patients } n=105 \\
\text { Healthy controls } n=53\end{array}$ & Case-control & $\begin{array}{l}\text { ESKD GFR } \\
\mathrm{d} 15 \mathrm{~mL} / \mathrm{min} / 1.73 \mathrm{~m}^{2}\end{array}$ & No case definition used & t-test \\
\hline $\begin{array}{l}\text { Ioannidou \& } \\
\text { Swede } 2011^{36}\end{array}$ & USA & $\begin{array}{l}\text { 12,081 adults e21 and d60 } \\
\text { years (NHANES III) } \\
\text { Non-Hispanic Whites } \\
\begin{array}{l}\text { CKD } n=437 \& \text { Non-CKD } \\
n=4,216\end{array} \\
\begin{array}{l}\text { Non-Hispanic Blacks } \\
\text { CKD } n=88 \& \text { Non-CKD } \\
n=3,182\end{array} \\
\text { Mexican-Americans }\end{array}$ & Cross-sectional & $\begin{array}{l}\text { GFR e } 15 \& \text { \& } \\
\mathrm{d} 89 \mathrm{~mL} / \mathrm{min} / 1.73 \mathrm{~m}^{2}\end{array}$ & $\begin{array}{l}\text { CDC/AAP } \\
\text { Moderate } \\
\text { e2 IP sites with e } 3 \mathrm{~mm} \\
\text { CAL \& e } 2 \text { IP sites with } \\
\text { e } 4 \mathrm{~mm} \\
\text { PPD or e } 1 \text { site with PPD } \\
\text { e } 5 \mathrm{~mm} \text {. }\end{array}$ & $\begin{array}{l}\text { Multivariable logistic } \\
\text { regression modelling }\end{array}$ \\
\hline
\end{tabular}




\begin{tabular}{|c|c|c|c|c|c|c|}
\hline & & CKD $\mathrm{n}=81 \&$ Non-CKD 3,600 & & & & \\
\hline $\begin{array}{l}\text { Marakoglu et } \\
\text { al } 2003^{37}\end{array}$ & Turkey & $\begin{array}{l}72 \text { subjects in total } \\
\text { Hemodialysis } n=36 \\
\text { Systemically healthy } \\
\text { periodontitis control } n=36\end{array}$ & Cross-sectional & $\begin{array}{l}\text { ESKD } \\
\text { GFR d } 15 \mathrm{~mL} / \mathrm{min} / 1.73 \mathrm{~m}^{2}\end{array}$ & No formal case definition & t-test \& ANOVA \\
\hline $\begin{array}{l}\text { Sharma et al } \\
2014^{38}\end{array}$ & $\begin{array}{l}\text { United } \\
\text { Kingdom }\end{array}$ & $\begin{array}{l}469 \text { patients with stage } \mathrm{e} 3 \\
\text { CKD in total } \\
\text { Dentate } \mathrm{n}=389 \\
\text { Edentulous } \mathrm{n}=80 \\
\text { ADHS cohort } \mathrm{n}=876 \text { patients } \\
\text { recruited from the West } \\
\text { Midlands region }\end{array}$ & Cross-sectional & GFR $<60 \mathrm{~mL} / \mathrm{min} / 1.73 \mathrm{~m}^{2}$ & $\begin{array}{l}\text { CDC/AAP \& EFP case } \\
\text { definitions. } \\
\text { Moderate: e } 1 \text { tooth with } \\
\text { PD e 4mm } \\
\text { Severe e } 1 \text { tooth with PD } \\
\text { e } 6 \mathrm{~mm}\end{array}$ & $\begin{array}{l}\text { chi square \& } \\
\text { multivariable logistic } \\
\text { regression }\end{array}$ \\
\hline $\begin{array}{l}\text { Tiwari et al } \\
2013^{39}\end{array}$ & India & $\begin{array}{l}60 \text { participants in total: } \\
30 \mathrm{CKD} \text { on dialysis } \\
30 \text { age \& sex-matched } \\
\text { systemically healthy controls }\end{array}$ & Case-control & $\begin{array}{l}\text { ESKD GFR } \\
\mathrm{d} 15 \mathrm{~mL} / \mathrm{min} / 1.73 \mathrm{~m}^{2}\end{array}$ & CPITN & t-test \\
\hline $\begin{array}{l}\text { Torres et al } \\
2010^{40}\end{array}$ & Brazil & $\begin{array}{l}30 \text { participants in total: } \\
16 \text { ESKD patients on dialysis } \\
14 \text { Systemically healthy } \\
\text { periodontitis patients }\end{array}$ & Case-control & $\begin{array}{l}\text { ESKD GFR } \\
\mathrm{d} 15 \mathrm{~mL} / \mathrm{min} / 1.73 \mathrm{~m}^{2}\end{array}$ & No case definition used & t-test \\
\hline
\end{tabular}


Table 2: Observational Studies: CKD associated with Periodontitis (cont.)

\begin{tabular}{|c|c|c|c|c|}
\hline Authors & $\begin{array}{l}\text { Effect size and Crude Association } \\
\text { with } 95 \% \text { CI }\end{array}$ & Adjusted effect & $\begin{array}{l}\text { Variables used in adjusted } \\
\text { models }\end{array}$ & NOS quality assessment \\
\hline Bastos et al $2011^{33}$ & $\begin{array}{l}\text { Pre-dialysis group had significantly } \\
\text { higher extent of PPD e } 5 \mathrm{~mm}(21.8 \pm \\
\text { 23.4) than non-CKD patients }(8.3 \pm \\
\text { 7.7) but not RRT patients }(14.1 \pm 14.6) \\
\text { RRT group had significantly higher } \\
\text { extent of CAL e } 6 \mathrm{~mm} 26.7 \pm 27.8 \\
\text { compared to non-CKD } 6.7 \pm 8.5 \text {. }\end{array}$ & Not reported & N/A & Moderate \\
\hline Garcez et al $2009^{34}$ & $\begin{array}{l}\text { mean PPD: Decreased GFR }(0.65 \pm \\
0.75) \text { versus control }(0.56 \pm 0.79) ; \\
\text { mean CAL: Decreased GFR }(0.54 \pm \\
0.60) \text { versus control }(0.44 \pm 0.56)\end{array}$ & Not reported & N/A & Moderate \\
\hline Gavalda et al $1999^{35}$ & $\begin{array}{l}\text { There was no significant difference in } \\
\text { mean LPA between Hemodialysis } \\
\text { group mean }(4.9 \pm 2.1) \text { versus }(4.2 \pm \\
2.5) \text {. }\end{array}$ & Not reported & N/A & Low \\
\hline $\begin{array}{l}\text { Ioannidou \& Swede } \\
2011^{36}\end{array}$ & $\begin{array}{l}\text { Non-CKD ref } \\
\text { Non-Hispanic Blacks OR } 1.85(1.48- \\
2.30) \\
\text { Mexican American OR } 2.77(2.15- \\
3.55)\end{array}$ & $\begin{array}{l}\text { Non-CKD ref } \\
\text { Non-Hispanic Blacks Adj } \\
\text { OR } 1.24(0.95-1.62) \\
\text { Mexican American Adj } \\
\text { OR } 1.59(1.14-2.13)\end{array}$ & $\begin{array}{l}\text { Age, sex, smoking, diabetic } \\
\text { status, diabetic control \& } \\
\text { duration, BMI, CVD, } \\
\text { hypertension, health } \\
\text { perception, income and } \\
\text { education }\end{array}$ & High \\
\hline Marakoglu et al $2003^{37}$ & $\begin{array}{l}\text { No significant differences between } \\
\text { groups in terms of mean PPD (HD } 1.8 \\
\pm 0.6 \text { vs control } 1.8 \pm 0.6) \text {. } \\
\text { No difference in frequency of PPD 3-6 } \\
\text { mm between groups (both } 8 \% \text { ) } \\
\text { Control group had more participants } \\
\text { with PPD e } 6 \mathrm{~mm}(11 \%) \text { compared to }\end{array}$ & Not reported & $\mathrm{N} / \mathrm{A}$ & High \\
\hline
\end{tabular}

This article is protected by copyright. All rights reserved. 


\begin{tabular}{|c|c|c|c|c|}
\hline & HD group ( $0 \%)$ & & & \\
\hline Sharma et al $2014^{38}$ & $\begin{array}{l}\text { ADHS ref. vs whole RIISC cohort. } \\
\text { Moderate/severe PD OR } 4.93(3.42 \text { - } \\
7.10) \\
\text { Severe PD OR } 4.75(3.31-6.83)\end{array}$ & $\begin{array}{l}\text { ADHS ref. vs whole } \\
\text { RIISC cohort. } \\
\text { Moderate/severe PD Adj } \\
\text { OR } 3.96(2.65-5.90) \\
\text { Severe PD Adj OR } 3.77 \\
(2.52-5.65)\end{array}$ & $\begin{array}{l}\text { Age, gender, ethnicity, } \\
\text { smoking status, SES. }\end{array}$ & Moderate \\
\hline Tiwari et al $2013^{39}$ & $\begin{array}{l}\text { No significant difference in PPD } \\
\text { between groups: ESKD mean } 5.53 \pm \\
2.53 \text { compared to healthy controls } 1.86 \\
\pm 1.26 \text {. }\end{array}$ & Not reported & N/A & Low \\
\hline Torres et al $2010^{40}$ & $\begin{array}{l}\text { Mean pocketing was significantly } \\
\text { lower in ESKD group }(1.77 \pm 0.32) \\
\text { compared to periodontitis control group } \\
(2.65 \pm 0.53) \text {. }\end{array}$ & Not reported & $\mathrm{N} / \mathrm{A}$ & Moderate \\
\hline
\end{tabular}

Abbreviations: GFR: glomerular filtration rate; CKD: chronic kidney disease; ESKD: end-stage kidney disease; CRF: Chronic Renal Failure; RRT: renal replacement therapy; HD: Hemodialysis; CAPD: Continual Ambulatory Perioteneal Dialysis; CRP: C-reactive protein; PPD: probing pocket depth; CAL: clinical attachment level; LPA: loss of periodontal attachment; IP: interproximal; BOP: bleeding on probing; CPI/TN: Community Periodontal Index/of Treatment Needs; NHANES: National Health and Nutritional Examination Survey; ARIC: Atherosclerosis Risk in Communities Study; ADHS: Adult Dental Health Study; RIISC: Renal Impairment in Secondary Care cohort study; CDC/AAP: Centres for Disease Control and Prevention and American Academy of Periodontology; EFP: European Federation of Periodontology; PD: periodontal disease. 
FIGURE 1: Flow diagram of the search process

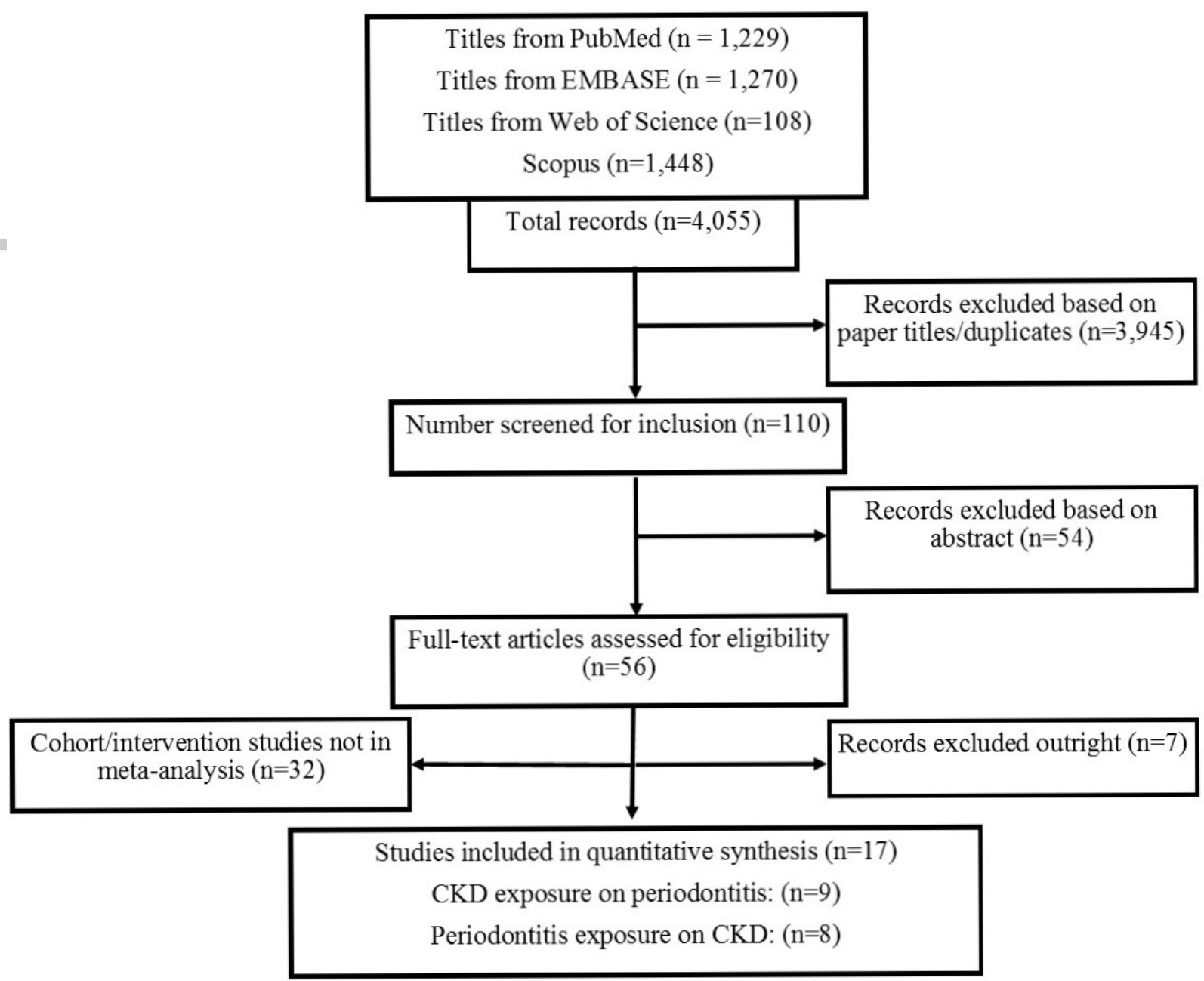

This article is protected by copyright. All rights reserved. 
FIGURE 2A: Forrest plot for the association between periodontal disease and the outcome of chronic kidney disease, stratified according to appraisal quality scores

\begin{tabular}{|c|c|c|c|}
\hline \multicolumn{2}{|l|}{ Author/Year } & \multirow[t]{2}{*}{ ES (95\% Cl) } & $\begin{array}{l}\% \\
\text { Weight }\end{array}$ \\
\hline High & & & \\
\hline Chen et al 2015 & 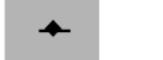 & $1.59(1.37,1.86)$ & 53.39 \\
\hline Fisher et al 2008 & 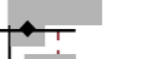 & $1.20(0.76,1.90)$ & 5.94 \\
\hline Grubbs et al 2011 & $\rightarrow$ & $1.51(1.13,2.02)$ & 14.79 \\
\hline Grubbs et al 2015 & & $4.18(1.68,10.39)$ & 1.50 \\
\hline Grubbs et al 2016 & $\frac{1}{10}$ & $2.04(1.21,3.44)$ & 4.57 \\
\hline Han et al 2013 & $\rightarrow$ & $1.39(1.03,1.89)$ & 13.55 \\
\hline Kshirsagar et al 2005 & + & $2.14(1.19,3.85)$ & 3.62 \\
\hline Kshirsagar et al 2007 & & $8.20(1.61,41.82)$ & 0.47 \\
\hline Subtotal $(I-$ squared $=43.6 \%, p=0.088$ ) & 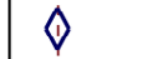 & $1.59(1.42,1.78)$ & 97.83 \\
\hline \multicolumn{4}{|l|}{ Moderate } \\
\hline Iwasaki et al 2012 & & $2.24(1.05,4.79)$ & 2.17 \\
\hline Subtotal $(\mathrm{I}$-squared $=. \%, \mathrm{p}=$. ) & & $2.24(1.05,4.78)$ & 2.17 \\
\hline \multicolumn{4}{|l|}{ Heterogeneity between groups: $p=0.384$} \\
\hline Overall $(I-$ squared $=39.2 \%, p=0.106)$ & $\diamond$ & $1.60(1.44,1.79)$ & 100.00 \\
\hline .0239 & 1 & .8 & \\
\hline
\end{tabular}


FIGURE 2B: Forrest plot showing the association between chronic kidney disease and the outcome of periodontal disease, stratified according to appraisal quality scores

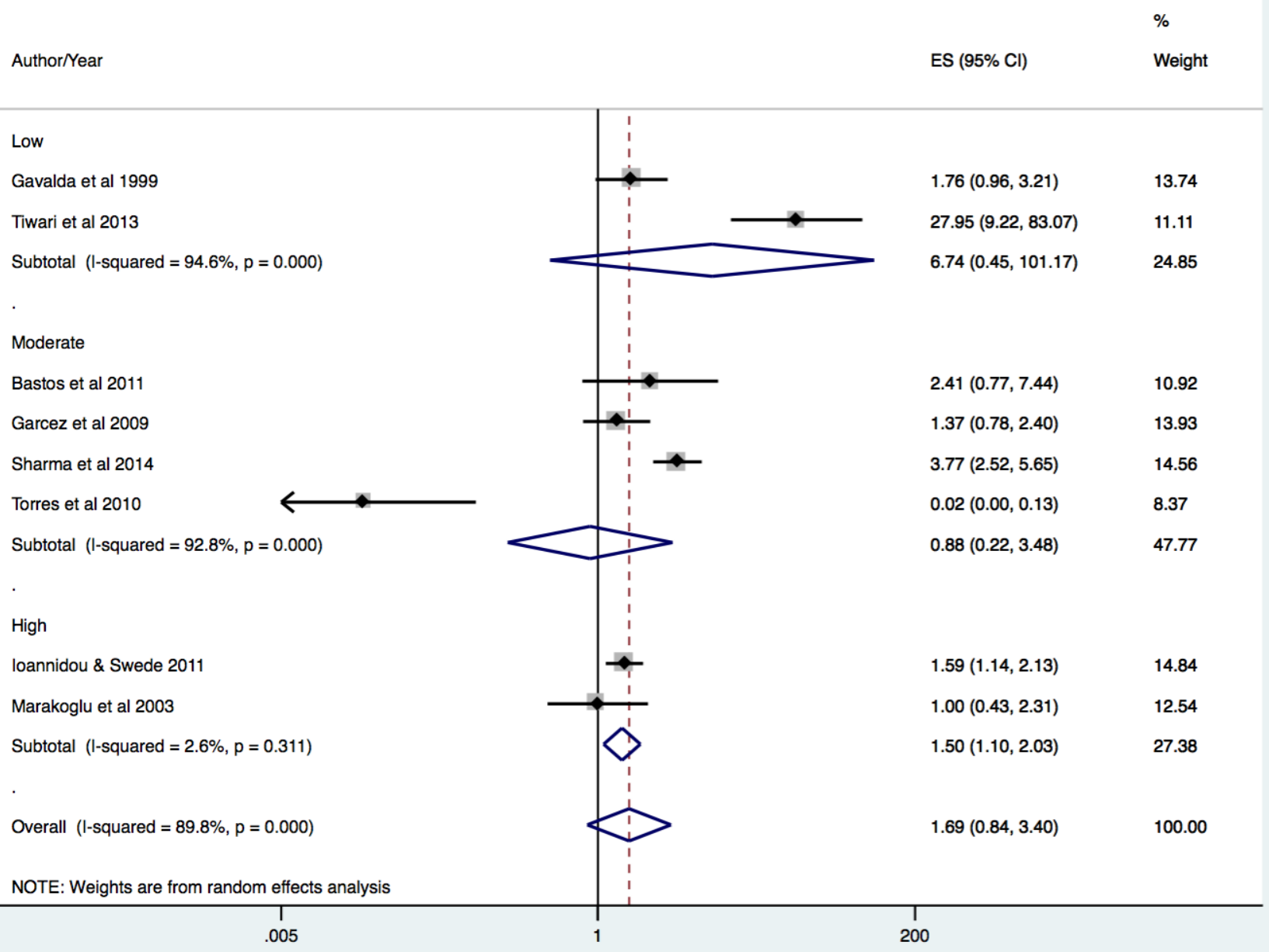

This article is protected by copyright. All rights reserved. 
FIGURE 2C: Funnel plots demonstrating the degree of bias and heterogeneity within the analysed studies for the association between periodontal disease and the outcome of chronic kidney disease

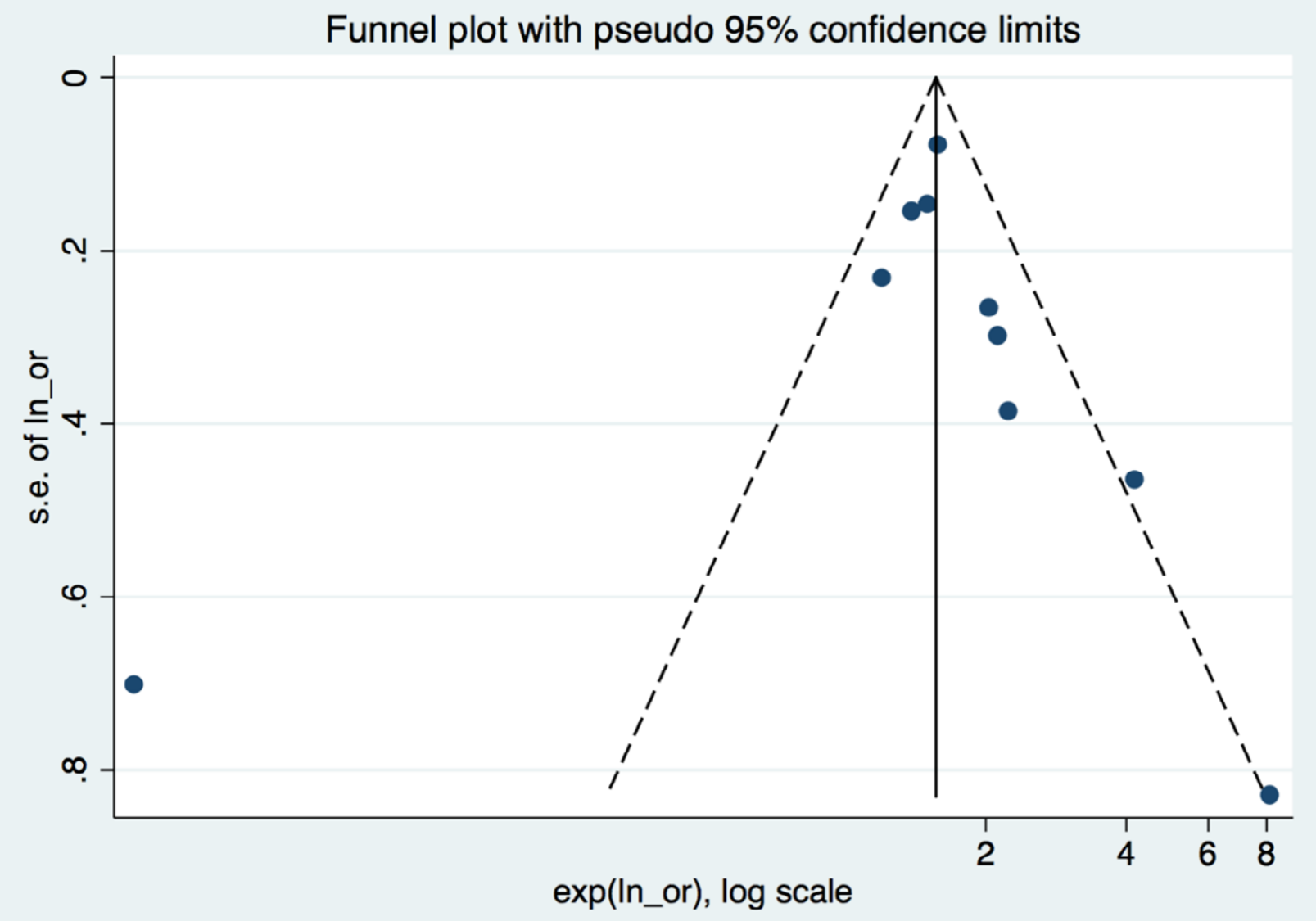

Egger's test for publication bias: $P=0.921$ 
FIGURE 2D: Funnel plots demonstrating the degree of bias and heterogeneity within the analysed studies for the association between chronic kidney disease and the outcome of periodontal disease

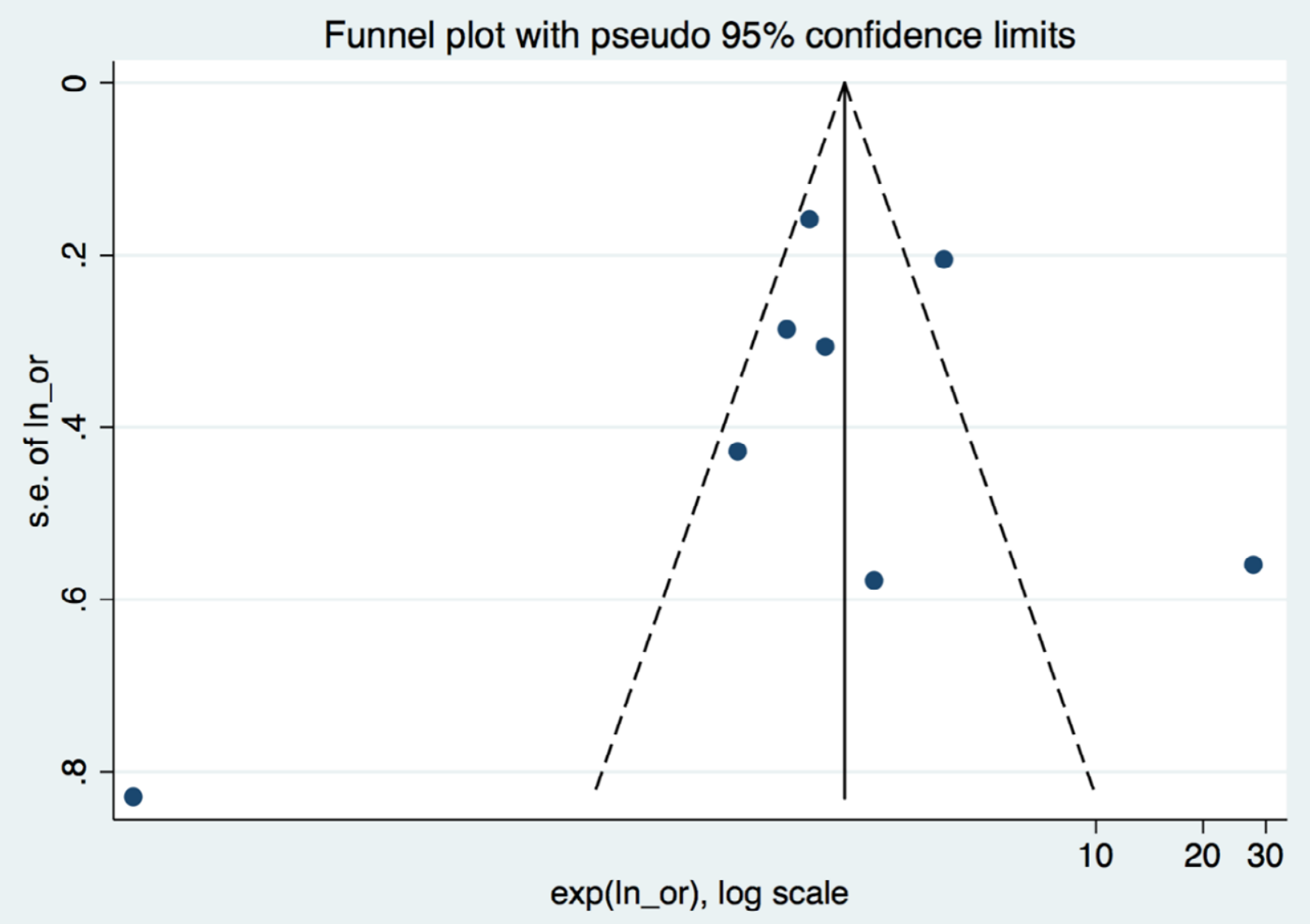

Egger's test for publication bias: $\mathrm{P}=0.688$ 


\section{University Library}

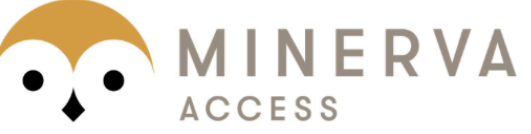

A gateway to Melbourne's research publications

Minerva Access is the Institutional Repository of The University of Melbourne

\section{Author/s:}

Kapellas, K;Singh, A;Bertotti, M;Nascimento, GG;Jamieson, LM;Hughes, J;Sajiv,

C;Fernandes, D;Pawar, B;Harris, D;Hoy, W;Cass, A;Maple-Brown, L;Brown, A;Skilton, M;Askie, L;Bartold, PM;Arrow, P

Title:

Periodontal and chronic kidney disease association: A systematic review and meta-analysis

Date:

2019-02-01

\section{Citation:}

Kapellas, K., Singh, A., Bertotti, M., Nascimento, G. G., Jamieson, L. M., Hughes, J., Sajiv, C., Fernandes, D., Pawar, B., Harris, D., Hoy, W., Cass, A., Maple-Brown, L., Brown, A., Skilton, M., Askie, L., Bartold, P. M. \& Arrow, P. (2019). Periodontal and chronic kidney disease association: A systematic review and meta-analysis. NEPHROLOGY, 24 (2), pp.202-212. https://doi.org/10.1111/nep.13225.

Persistent Link:

http://hdl.handle.net/11343/285384 